\title{
Efficacy of different natural herbs in improving qualitative, sensory and microbiological properties of wood apple jam
}

\author{
Arghya Mani ${ }^{\star}$ and Surajit Mitra ${ }^{\#}$ \\ School of Agriculture, Lovely Professional University, Phagwara-144411, Punjab, India. \\ Department of Post Harvest Technology, BCKV, Mohanpur-741252, West Bengal, India
}

\begin{tabular}{l} 
Article Info \\
\hline Article history \\
Received 12 March 2021 \\
Revised 29 April 2021 \\
Accepted 30 April 2021 \\
Published online 30 June 2021 \\
Keywords \\
Wood apple \\
Jam \\
Medicinal herbs \\
Mango ginger \\
Ashwagandha
\end{tabular}

\begin{abstract}
An experiment was conducted to study the effect of addition of different medicinal herbs like Ashwagandha powder @2\%, Tulsi extract @2\%, Mint extract @2\%, Lemon grass@2\% and Mango ginger @2\% on quality of wood apple jam. The jam was prepared using standardized process and was evaluated for quality, sensory and microbiological properties up to 12 months of ambient storage. After studying the jam for several biochemical and sensory parameters for 12 months, it was concluded that addition of $2 \%$ mango ginger resulted in the best quality of product. Mango ginger addition in wood apple jam resulted in higher retention of vitamin $\mathrm{C}$ content through out the storage. The antibacterial property of mango ginger was also evident with a lower total colony count. The sensory properties of the product blended with mango ginger $2 \%$ exhibited a very high hedonic score and acceptability. Hence, this treatment can be commercialized.
\end{abstract}

\section{Introduction}

Jam is a delicious food product which is prepared by cooking fruit pulp with sufficient quantity of sugar and pectin in presence of acid. Jam is a very popular processed product which is not only delicious but also nutritious. Jam can be prepared using several types of fruits including wood apple. Wood apple (Feronia limonia L.) belongs to the family Rutaceae and is an under exploited fruit in India. The fruit is rich in pectin (3-5\%) and is an excellent material for preparation of jam. Wood apple has got high medicinal value. Every part of the fruit possesses medicinal property. Fruits, leaves and stem bark of wood apple have been studied for anti-tumour and antimicrobial activity (Rahman and Gray, 2002). Fruit pulp has anti-inflammatory, antipyretic and analgesic activity (Ahamed et al., 2008). Wood apple has antidiabetic and antioxidant potential by reducing the level of blood glucose and malondialdehyde (Patel et al., 2012). Fruit is much used in India as a liver and cardiac tonic and when unripe, as a means of halting diarrhoea and dysentery and for effective treatment for high cough, sore throat and disease of the gums (Sonawane and Arya, 2013). In addition to this, wood apples also have hypoglycaemic activity, antitumour, larvicidal and antimicrobial activity and hepatoprotective activity (Vidhya and Narain, 2011). Wood apple fruit is considered to be one of the natural sources of antioxidants due to its potential radical scavenging activity of various phytochemicals (Nithya and Saraswathi, 2010). Processed products prepared from wood apple have superb thirst

Corresponding author: Dr. Arghya Mani

Assistant Professor, School of Agriculture, Lovely Professional University, Phagwara-144411, Punjab, India.

E-mail: arghyamani14@gmail.com

Tel.: +91-9800110988

quenching capability and have tremendous potential to be an important crop for processing. Traditionally in Indian homes, wood apple is even consumed raw but its exquisite flavour and perfect sour-sweet blend can be harnessed by value adding it in form of jam (Mani and Mitra, 2020).

Ashwagandha (Withania somnifera D.) is Indian ginseng which is both a tonic and a sedative due to its adaptogenic properties (Jana and Charan, 2018). Ashwagandha is also known to have a wide range of health benefits, including its ability to fight against cancer and diabetes, as well as reduce inflammation, arthritis, asthma, hypertension, stress and rheumatism (Verma and Kumar, 2011). Ashwagandha is effective in recovering from urogenital, gastrointestinal and respiratory tract infections when consumed orally (Apte, 2007). Tulsi (Ocimum sanctum L.) is believed to have health benefits due to their anthelmintic activity and polyphenols (Gangrade et al., 2000). Juice or infusion of the tulsi leaves used in the treatment of bronchitis, catarrh, digestive complaints, arthritis, ringworms, hypertension, heart attack, cancer, viral hepatitis and diabetes (Luthra, 2010). The leaves and seeds of tulsi are reported to have diuretic and laxative properties (Cohen, 2014). Lemon grass (Cymbopogon citratus $\mathrm{L}$.) can be widely used in food products due to its desirable aroma (Majewska et al., 2019). Lemon grass is used for treating digestive tract spasms, stomach ache, high blood pressure, pain, vomiting, cough, achy joints (rheumatism), fever, the common cold and exhaustion. It is also used to kill germs and as a mild astringent (Olorunnisola et al., 2014). Health benefits of lemongrass include relief from stomach disorders, fever, aches, infections, rheumatism andedema. It is antibiotic, antifungal and plays an important role to defeat cancer (Silva et al., 2008; Danlami et al., 2011). Mango ginger (Curcuma amada R.), is a plant of family Zingiberaceae and is closely related

Copyright $(\odot 2021$ Ukaaz Publications. All rights reserved.

Email: ukaaz@yahoo.com; Website: www.ukaazpublications.com 
to turmeric. The flavours of the rhizome are very similar to ginger but have a raw mango taste (Policegoudra, 2011; Rao et al., 1989). Mango ginger extracts are known to have cytotoxic activities on the human cancer cell lines MCF-7 (Malek et al., 2011). It is a rich source of antioxidants and also has antimicrobial properties (Tamta et al., 2016; Dosoky and Setzer, 2018).

Even though wood apple jam is slightly acidic in nature but it starts spoiling after 6 to 7 months of ambient storage. There is a dire need to enhance its shelf life and augment its sensory and quality characters. Considering these above factors, there appears a possibility to improve traditional wood apple jam using natural herbs like ashwagandha, tulsi extract, mint extract, lemon grass and mango ginger.

\section{Materials and Methods}

\subsection{Methodology of preparation of jam}

The wood apple jam was prepared according to the procedure as standardised by Vidhya and Narain (2011). At first perfectly ripened fruits were selected followed by extraction of wood apple fruit pulp. The pulp was weighed because the ingredients were added depending on pulp weight. The pulp was cooked in low - medium flame for $5 \mathrm{~min}$. The cooked pulp was sieved to remove seeds and fibres. Sugar was added to the jam at the rate of $750 \mathrm{~g}$ per kg pulp. Then, the natural product extract and herbs were added properly. The pulp was cooked slowly and occasionally stirred for 15-20 min. During the entire process of cooking, end point judgement was done to ensure over cooking and loss of vital nutrients. The product was ready when the TSS reading was $68.5^{\circ} \mathrm{B}$. The hot jam was filled in clean, dried and sterilized glass jars. The jars were lidded properly and stored in clean dry place.

Ingredients: The products were prepared with $100 \%$ wood apple pulp. In $\mathrm{T}_{6}$ (Control), no herbal extracts were added while preparation of jam. In other treatments, $2 \%$ herbal extracts were added while cooking of the pulp

\subsection{Experiment site}

This experiment was conducted in Post Graduate Lab, Department of Post-Harvest Technology, BCKV, Mohanpur in the year 2018 to 2019. Wood apple was purchased from Local Market and the processed product was prepared out of it. The design of the experiment is completely randomized design (CRD) with 6 treatments and 4 replications. Medicinal products like tulsi, lemon grass, mint and mango ginger were procured from Department of Plantation, Spice, Medicinal and Aromatic plants, BCKV.

\subsection{Storage study of jam}

The jam was stored in sterilized glass jar for 12 months. The stored jam was analyzed for several quality parameters, sensory and microbiological properties at an interval of 3 months up to 12 months of storage. The jam was stored at ambient conditions. The highest and lowest temperature during the year of study was $38^{\circ} \mathrm{C}$ and $12^{\circ} \mathrm{C}$, respectively. The humidity varies from $98 \%$ during monsoon to $45 \%$ during winter.

\subsection{Treatment details}

Jam was prepared by addition of the following medicinal products, aromatic herbs and spice. The treatment details were: $\mathrm{T}_{1}$-Wood apple pulp + ashwagandha @ 2\%; $\mathrm{T}_{2}$-Wood apple pulp + tulsi extract @ 2\%; $\mathrm{T}_{3}$-Wood apple pulp + mint extract @ 2\%; $\mathrm{T}_{4}$-Wood apple pulp + lemon grass @ 2\%; $\mathrm{T}_{5}$-Wood apple pulp + mango ginger @2\% and $\mathrm{T}_{6}$ - Control (no addition).

\subsection{Observations recorded}

TSS of the prepared jam was determined using a digital refractometer. Total sugar, reducing sugar, titratable acidity and ascorbic acid content of the prepared jam was determined according to the standard procedures (AOAC, 2012). $\mathrm{pH}$ value of the prepared jam was determined using a standard $\mathrm{pH}$ meter. Microbiological analysis for the pickle was carried out by the method of Ranganna (2010). All the enumerations of Bacteria and Lactobacillus were carried out following serial dilution technique using specific media. Plates were incubated at $34 \pm 1^{\circ} \mathrm{C}$ for $48 \mathrm{~h}$ and colony forming units (CFU/g) were recorded. Observations for microbial count were made at prescribed intervals. The principle behind this is that the population of total bacterial population tends to decline with the decimal reduction in the concentration of the sample analysed. Usually in a culture, the microbial population was expected to be higher in $10^{-1}$ which tends to decline with $10^{-2}, 10^{-3}, 10^{-4}, 10^{-5}$ and $10^{-6}$ sample concentration. Higher the sample concentration, higher would be the expected microbial concentration. As the colonies tends to coalesce or merge at higher concentration, hence the readings for Total Plate Count and Total Bacterial Population Count have been studied at $10^{-5}$ concentration. 9-point hedonic scale was used for the purpose of sensory evaluation of the prepared wood apple jam. Twenty judges of diverse age groups were asked to rate from 1 to 9 based on different columns like colour, texture, flavour, taste and overall organoleptic score (Peryam et al., 1957).

\section{Results}

\subsection{Physicochemical properties of wood apple used for jam} preparation

Table 1 shows the physicochemical property of wood apple used for jam preparation. It was observed that the fruits used for jam preparation have a TSS of $16.33^{\circ} \mathrm{B}$, titratable acidity of $5.48 \%$. Total sugar and reducing sugar content were $14.20 \%$ and $5.12 \%$, respectively. The ascorbic acid content was $11.97 \mathrm{mg} / 100 \mathrm{~g}$.

Table 1: Physicochemical properties of wood apple pulp used for jam preparation

\begin{tabular}{|l|c|}
\hline Attributes & Value per $\mathbf{1 0 0} \mathbf{g}$ \\
\hline TSS $\left({ }^{\circ} \mathrm{B}\right)$ & 16.33 \\
\hline Titratable acidity $(\%)$ & 5.48 \\
\hline Total sugar $(\%)$ & 14.20 \\
\hline Reducing sugar $(\%)$ & 5.12 \\
\hline Ascorbic acid $(\mathrm{mg} / 100 \mathrm{~g})$ & 11.97 \\
\hline
\end{tabular}

3.2 Change in total soluble solid (TSS) of jam during ambient storage

Table 2 highlights the effect of natural herbs on TSS $\left({ }^{\circ} \mathrm{B}\right)$ of wood apple jam during 12 months of ambient storage. During the storage period of 12 months, the total soluble solids $\left({ }^{\circ} \mathrm{B}\right)$ is steadily increasing. In all the treatments, TSS was $68.43^{\circ} \mathrm{B}$ which gradually 
increases with storage. At the $2^{\text {nd }}$ month of storage, TSS shows a slight increase up to $68.45^{\circ} \mathrm{B}$ in $\mathrm{T}_{1}, \mathrm{~T}_{2}, \mathrm{~T}_{3}, \mathrm{~T}_{4}$ and $\mathrm{T}_{5}$. In $\mathrm{T}_{6}$, the increase in TSS was slightly more which was $68.53{ }^{\circ} \mathrm{B}$. At $4^{\text {th }}$ month of storage, highest TSS was observed in $\mathrm{T}_{6}$ (Control) followed by $\mathrm{T}_{2}, \mathrm{~T}_{5}, \mathrm{~T}_{3}, \mathrm{~T}_{1}$ and $\mathrm{T}_{4}$ which was $68.73^{\circ} \mathrm{B}, 68.73^{\circ} \mathrm{B}, 68.68^{\circ} \mathrm{B}, 68.63^{\circ}$ $\mathrm{B}$ and $68.63^{\circ} \mathrm{B}$, respectively. At $6^{\text {th }}$ month of storage, highest TSS was observed in $\mathrm{T}_{6}$ followed by $\mathrm{T}_{4}, \mathrm{~T}_{3}, \mathrm{~T}_{1}, \mathrm{~T}_{5}$ and $\mathrm{T}_{2}$ which was $70.03^{\circ} \mathrm{B}, 69.15^{\circ} \mathrm{B}, 69.05^{\circ} \mathrm{B}, 69.00^{\circ} \mathrm{B}, 68.88^{\circ} \mathrm{B}$ and $68.83^{\circ} \mathrm{B}$, respectively. At $8^{\text {th }}$ month of storage, highest TSS was observed in $\mathrm{T}_{6}$ followed by $\mathrm{T}_{4}, \mathrm{~T}_{3}, \mathrm{~T}_{1}, \mathrm{~T}_{5}$ and $\mathrm{T}_{2}$ which was $70.18^{\circ} \mathrm{B}, 69.33^{\circ} \mathrm{B}$, $69.00^{\circ} \mathrm{B}, 68.98^{\circ} \mathrm{B}, 68.98^{\circ} \mathrm{B}$ and $68.90^{\circ} \mathrm{B}$, respectively. At $10^{\text {th }}$ month of storage, highest TSS was observed in $\mathrm{T}_{6}$ followed by $\mathrm{T}_{4}, \mathrm{~T}_{3}, \mathrm{~T}_{2}$, $\mathrm{T}_{1}$ and $\mathrm{T}_{5}$ which was $72.50^{\circ} \mathrm{B}, 70.43^{\circ} \mathrm{B}, 70.33^{\circ} \mathrm{B}, 70.25^{\circ} \mathrm{B}, 69.98^{\circ}$ $\mathrm{B}$ and $69.68^{\circ} \mathrm{B}$, respectively. At $12^{\text {th }}$ month of storage, highest TSS was observed in $T_{6}$ followed by $T_{4}, T_{2}, T_{3}, T_{1}$ and $T_{5}$ which was $74.18^{\circ} \mathrm{B}, 71.68^{\circ} \mathrm{B}, 71.08^{\circ} \mathrm{B}, 71.08^{\circ} \mathrm{B}, 70.98^{\circ} \mathrm{B}$ and $70.18^{\circ} \mathrm{B}$, respectively.

\subsection{Change in titratable acidity of jam during ambient storage}

Table 3 depicts the effect of natural herbs on titratable acidity (\%) of wood apple jam during 12 months of ambient storage. Throughout the storage period, there is a constant decrease in the titratable acidity. A drastic change in titratable acidity is not evident in this case. Treatments do not have significant effect on titratable acidity of wood apple jam throughout the storage period. At 0 months of storage, highest titratable acidity $(\%)$ was observed in $\mathrm{T}_{4}$ and $\mathrm{T}_{5}$ which was $0.95 \%$ and $0.95 \% . \mathrm{T}_{2}, \mathrm{~T}_{3}, \mathrm{~T}_{6}$ and $\mathrm{T}_{1}$ also shows a titratable acidity of $0.93 \%, 0.93 \%, 0.93 \%$ and $0.92 \%$, respectively. At $2^{\text {nd }}$ month of storage, highest titratable acidity was observed in $\mathrm{T}_{4}, \mathrm{~T}_{5}, \mathrm{~T}_{3}, \mathrm{~T}_{6}, \mathrm{~T}_{1}$ and $\mathrm{T}_{2}$ which was $0.94 \%, 0.94 \%, 0.93 \%, 0.92 \%$, $0.91 \%$ and $0.91 \%$, respectively. At $4^{\text {th }}$ month of storage, highest titratable acidity was observed in $\mathrm{T}_{4}$ and $\mathrm{T}_{5}$ followed by $\mathrm{T}_{3}, \mathrm{~T}_{1}, \mathrm{~T}_{2}$ and $\mathrm{T}_{6}$ which was $0.94 \%, 0.94 \%, 0.92 \%, 0.9 \%, 0.9 \%$ and $0.9 \%$, respectively. At $6^{\text {th }}$ month of storage, highest titratable acidity was observed in $\mathrm{T}_{4}$ and $\mathrm{T}_{5}$ followed by $\mathrm{T}_{3}, \mathrm{~T}_{6}, \mathrm{~T}_{1}$ and $\mathrm{T}_{2}$ which was $0.93 \%, 0.93 \%, 0.91 \%, 0.89 \%, 0.88 \%$ and $0.88 \%$, respectively. At $8^{\text {th }}$ month of storage, highest titratable acidity was observed in $\mathrm{T}_{4}$ followed by $\mathrm{T}_{3}, \mathrm{~T}_{5}, \mathrm{~T}_{1}, \mathrm{~T}_{2}$ and $\mathrm{T}_{6}$ which was $0.93 \%, 0.91 \%, 0.91 \%$, $0.88 \%, 0.87 \%$ and $0.87 \%$, respectively. At $10^{\text {th }}$ month of storage, highest titratable acidity was observed in $\mathrm{T}_{3}$ followed by $\mathrm{T}_{5}, \mathrm{~T}_{1}$, $\mathrm{T}_{2}, \mathrm{~T}_{4}$ and $\mathrm{T}_{6}$ which was $0.9 \%, 0.9 \%, 0.89 \%, 0.89 \%, 0.88 \%$ and $0.85 \%$, respectively. At $12^{\text {th }}$ month of storage, highest titratable acidity was observed in $\mathrm{T}_{1}$ and $\mathrm{T}_{3}$ followed by $\mathrm{T}_{2} \mathrm{~T}_{5}, \mathrm{~T}_{4}$ and $\mathrm{T}_{6}$ which was $0.90 \%, 0.90 \%, 0.89 \%, 0.89 \%, 0.88 \%$ and $0.84 \%$, respectively.

Table 2: Effect of natural herbs on TSS $\left({ }^{\circ} \mathrm{B}\right)$ of wood apple jam

\begin{tabular}{|l|c|c|c|c|c|c|c|}
\hline \multicolumn{1}{|c|}{ Treatment details } & \multicolumn{9}{c|}{ Months of storage } \\
\cline { 2 - 7 } & $\mathbf{0}$ & $\mathbf{2}$ & $\mathbf{4}$ & $\mathbf{6}$ & $\mathbf{8}$ & $\mathbf{1 0}$ & $\mathbf{1 2}$ \\
\hline $\mathrm{T}_{1}$ (Wood apple pulp + ashwagandha powder @2\%) & 68.43 & 68.45 & 68.63 & 69.00 & 68.98 & 69.98 & 70.98 \\
$\mathrm{~T}_{2}$ (Wood apple pulp + tulsi extract @2\%) & 68.43 & 68.45 & 68.73 & 68.83 & 68.90 & 70.25 & 71.08 \\
$\mathrm{~T}_{3}$ (Wood apple pulp + mint extract @2\%) & 68.43 & 68.45 & 68.68 & 69.05 & 69.00 & 70.33 & 71.08 \\
$\mathrm{~T}_{4}$ (Wood apple pulp + lemon grass @2\%) & 68.43 & 68.45 & 68.63 & 69.15 & 69.33 & 70.43 & 71.68 \\
$\mathrm{~T}_{5}$ (Wood apple pulp + mango ginger @2\%) & 68.43 & 68.45 & 68.73 & 68.88 & 68.98 & 69.68 & 70.18 \\
$\mathrm{~T}_{6}$ (Control) & 68.43 & 68.53 & 69.00 & 70.03 & 70.18 & 72.50 & 74.18 \\
S.E. $( \pm)$ & 0.22 & 0.22 & 0.03 & 0.03 & 0.05 & 0.03 & 0.14 \\
C.D. at 5\% & NA & NA & 0.09 & 0.09 & 0.14 & 0.10 & 0.43 \\
\hline
\end{tabular}

Table 3: Effect of natural herbs on titratable acidity (\%) of wood apple jam

\begin{tabular}{|l|c|c|c|c|c|c|c|}
\hline \multicolumn{1}{|c|}{ Treatment details } & \multicolumn{9}{c|}{ Months of storage } \\
\cline { 2 - 7 } & $\mathbf{0}$ & $\mathbf{2}$ & $\mathbf{4}$ & $\mathbf{6}$ & $\mathbf{8}$ & $\mathbf{1 0}$ & $\mathbf{1 2}$ \\
\hline $\mathrm{T}_{1}$ (Wood apple pulp + ashwagandha powder @2\%) & 0.92 & 0.91 & 0.90 & 0.88 & 0.88 & 0.89 & 0.90 \\
$\mathrm{~T}_{2}$ (Wood apple pulp + tulsi extract @2\%) & 0.93 & 0.91 & 0.90 & 0.88 & 0.87 & 0.89 & 0.89 \\
$\mathrm{~T}_{3}$ (Wood apple pulp + mint extract @2\%) & 0.93 & 0.93 & 0.92 & 0.91 & 0.91 & 0.90 & 0.90 \\
$\mathrm{~T}_{4}$ (Wood apple pulp + lemon grass @2\%) & 0.95 & 0.94 & 0.94 & 0.93 & 0.93 & 0.88 & 0.88 \\
$\mathrm{~T}_{5}$ (Wood apple pulp + mango ginger @2\%) & 0.95 & 0.94 & 0.94 & 0.93 & 0.91 & 0.90 & 0.89 \\
$\mathrm{~T}_{6}$ (Control) & 0.93 & 0.92 & 0.9 & 0.89 & 0.87 & 0.85 & 0.84 \\
S.E. $( \pm)$ & 0.02 & 0.01 & 0.02 & 0.03 & 0.03 & 0.02 & 0.02 \\
C.D. at 5\% & N/A & N/A & N/A & N/A & N/A & N/A & N/A \\
\hline
\end{tabular}

\subsection{Change in $\mathrm{pH}$ of jam during ambient storage}

Table 4 highlights the effect of natural herbs on $\mathrm{pH}$ of wood apple jam during 12 months of ambient storage. Throughout the storage period, there is a constant increase in the $\mathrm{pH}$ of prepared jam. At 0 days of storage, $\mathrm{pH}$ reading was highest in $\mathrm{T}_{3}$ followed by $\mathrm{T}_{1}, \mathrm{~T}_{2}$, $\mathrm{T}_{6}, \mathrm{~T}_{4}$ and $\mathrm{T}_{5}$ which was $3.15,3.14,3.14,3.14,3.13$ and 3.13 , respectively. At $2^{\text {nd }}$ month of storage highest $\mathrm{pH}$ was observed in $\mathrm{T}_{3}$ followed by $\mathrm{T}_{4}, \mathrm{~T}_{1}, \mathrm{~T}_{2}, \mathrm{~T}_{6}$ and $\mathrm{T}_{5}$ which was $3.17,3.16,3.15$,
$3.15,3.15$ and 3.13 , respectively. At $4^{\text {th }}$ month of storage, highest $\mathrm{pH}$ was observed in $\mathrm{T}_{3}, \mathrm{~T}_{2}, \mathrm{~T}_{4}, \mathrm{~T}_{1}, \mathrm{~T}_{6}$ and $\mathrm{T}_{5}$ which was $3.18,3.17$, $3.17,3.16,3.15$ and 3.13 , respectively. At $6^{\text {th }}$ month of storage, highest $\mathrm{pH}$ was observed in $\mathrm{T}_{3}$ and $\mathrm{T}_{4}$ followed by $\mathrm{T}_{1}, \mathrm{~T}_{2}, \mathrm{~T}_{6}$ and $\mathrm{T}_{5}$ which was 3.19, 3.19, 3.18, 3.18, 3.17 and 3.14, respectively. At $8^{\text {th }}$ month of treatment highest $\mathrm{pH}$ value was observed in $\mathrm{T}_{3}, \mathrm{~T}_{4}$ and $\mathrm{T}_{6}$ followed by $\mathrm{T}_{1}, \mathrm{~T}_{2}$ and $\mathrm{T}_{5}$ which was $3.2,3.2,3.2,3.19,3.19$ and 3.15 , respectively. At $10^{\text {th }}$ month of storage, highest $\mathrm{pH}$ reading 
was observed in $\mathrm{T}_{6}$ followed by $\mathrm{T}_{4}, \mathrm{~T}_{2}, \mathrm{~T}_{3}, \mathrm{~T}_{1}$ and $\mathrm{T}_{5}$ which was $3.24,3.23,3.21,3.21,3.2$ and 3.17, respectively. At $12^{\text {th }}$ month of storage, highest $\mathrm{pH}$ value was observed in $\mathrm{T}_{6}$ (Control), $\mathrm{T}_{4}, \mathrm{~T}_{2}, \mathrm{~T}_{1}$, $\mathrm{T}_{3}$ and $\mathrm{T}_{5}$ which was $3.29,3.25,3.23,3.22,3.22$ and 3.18 , respectively.

\subsection{Change in total sugar content of jam during ambient storage}

Table 5 depicts the effect of different medicinal herbs on total sugar content of wood apple jam under 12 months of ambient storage. A clear increase in total sugar content of the jam was observed during the storage in all the treatments. At 0 days of storage, highest total sugar content was observed in $\mathrm{T}_{6}$ (Control) followed by $\mathrm{T}_{5}, \mathrm{~T}_{1}, \mathrm{~T}_{4}$, $\mathrm{T}_{2}$ and $\mathrm{T}_{3}$ which is $56.24 \%, 56.23 \%, 56.2 \%, 56.18 \%, 56.17 \%$ and $56.13 \%$, respectively. No significant difference among treatment was observed. At $2^{\text {nd }}$ month of storage, highest total sugar content was observed in $\mathrm{T}_{6}$ followed by $\mathrm{T}_{3}, \mathrm{~T}_{4}, \mathrm{~T}_{1}, \mathrm{~T}_{5}$ and $\mathrm{T}_{2}$ which was $57.24 \%, 57.19 \%, 57.19 \%, 57.10 \%, 57.10 \%$ and $57.04 \%$, respectively. No significant difference among treatment was observed. At $4^{\text {th }}$ month of storage, highest total sugar content was observed in $\mathrm{T}_{6}$ (Control) followed by $\mathrm{T}_{3}, \mathrm{~T}_{1}, \mathrm{~T}_{4}, \mathrm{~T}_{2}$ and $\mathrm{T}_{5}$ which was $58.48 \%, 58.30 \%, 58.29 \%, 58.24 \%, 58.07 \%$ and $58.04 \%$, respectively. No significant difference among treatment was observed even at $4^{\text {th }}$ month of storage. At $6^{\text {th }}$ month of storage, highest total sugar content was observed in $\mathrm{T}_{6}$ (Control) followed by $\mathrm{T}_{5}, \mathrm{~T}_{4}, \mathrm{~T}_{3}, \mathrm{~T}_{2}$ and $\mathrm{T}_{1}$ which was $61.00 \%, 58.60 \%, 59.55 \%$, $59.45 \%, 59.24 \%$ and $59.14 \%$, respectively. At $8^{\text {th }}$ month of storage, highest total sugar content was observed in $\mathrm{T}_{6}$ (Control) followed by $\mathrm{T}_{4}, \mathrm{~T}_{1}, \mathrm{~T}_{3}, \mathrm{~T}_{2}$ and $\mathrm{T}_{5}$ which was $63.89 \%, 60.82 \%, 60.45 \%$, $60.39 \%, 60.31 \%$ and $59.2 \%$, respectively. At $10^{\text {th }}$ month of storage, highest total sugar content was observed in $\mathrm{T}_{6}$ (Control) followed by $\mathrm{T}_{4}, \mathrm{~T}_{3}, \mathrm{~T}_{2}, \mathrm{~T}_{1}$ and $\mathrm{T}_{5}$ which was $65.22 \%, 62.35 \%, 61.48 \%$, $61.26 \%, 61.14 \%$ and $60.51 \%$, respectively. At $12^{\text {th }}$ month of storage, highest total sugar content was observed in $\mathrm{T}_{6}$ followed by $\mathrm{T}_{2}, \mathrm{~T}_{1}$, $\mathrm{T}_{4}, \mathrm{~T}_{3}$ and $\mathrm{T}_{5}$ which was $67.45 \%, 63.27 \%, 63.20 \%, 63.17 \%, 63.03 \%$ and $62.59 \%$, respectively.

Table 4: Effect of natural herbs on $\mathrm{pH}$ of wood apple jam

\begin{tabular}{|l|c|c|c|c|c|c|c|}
\hline \multicolumn{1}{|c|}{ Treatment details } & \multicolumn{9}{c|}{ Months of storage } \\
\cline { 2 - 8 } & $\mathbf{0}$ & $\mathbf{2}$ & $\mathbf{4}$ & $\mathbf{6}$ & $\mathbf{8}$ & $\mathbf{1 0}$ & $\mathbf{1 2}$ \\
\hline $\mathrm{T}_{1}$ (Wood apple pulp + ashwagandha powder @ 2\%) & 3.14 & 3.15 & 3.16 & 3.18 & 3.19 & 3.2 & 3.22 \\
$\mathrm{~T}_{2}$ (Wood apple pulp + tulsi extract @ 2\%) & 3.14 & 3.15 & 3.17 & 3.18 & 3.19 & 3.21 & 3.23 \\
$\mathrm{~T}_{3}$ (Wood apple pulp + mint extract @ 2\%) & 3.15 & 3.17 & 3.18 & 3.19 & 3.20 & 3.21 & 3.22 \\
$\mathrm{~T}_{4}$ (Wood apple pulp + lemon grass @ 2\%) & 3.13 & 3.16 & 3.17 & 3.19 & 3.20 & 3.23 & 3.25 \\
$\mathrm{~T}_{5}$ (Wood apple pulp + mango ginger @2\%) & 3.13 & 3.13 & 3.13 & 3.14 & 3.15 & 3.17 & 3.18 \\
$\mathrm{~T}_{6}$ (Control) & 3.14 & 3.15 & 3.15 & 3.17 & 3.20 & 3.24 & 3.29 \\
S.E. $( \pm)$ & 0.02 & 0.02 & 0.02 & 0.03 & 0.01 & 0.02 & 0.02 \\
C.D. at 5\% & N/A & N/A & N/A & N/A & N/A & N/A & N/A \\
\hline
\end{tabular}

Table 5: Effect of natural herbs on total sugar (\%) of wood apple jam

\begin{tabular}{|l|c|c|c|c|c|c|c|}
\hline \multicolumn{2}{|c|}{ Treatment details } & \multicolumn{7}{c|}{ Months of storage } \\
\cline { 2 - 7 } & $\mathbf{0}$ & $\mathbf{2}$ & $\mathbf{4}$ & $\mathbf{6}$ & $\mathbf{8}$ & $\mathbf{1 0}$ & $\mathbf{1 2}$ \\
\hline $\mathrm{T}_{1}$ (Wood apple pulp + ashwagandha powder @2\%) & 56.20 & 57.10 & 58.29 & 59.14 & 60.45 & 61.14 & 63.20 \\
$\mathrm{~T}_{2}$ (Wood apple pulp + tulsi extract @2\%) & 56.17 & 57.04 & 58.07 & 59.24 & 60.31 & 61.26 & 63.27 \\
$\mathrm{~T}_{3}$ (Wood apple pulp + mint extract @2\%) & 56.13 & 57.19 & 58.30 & 59.45 & 60.39 & 61.48 & 63.03 \\
$\mathrm{~T}_{4}$ (Wood apple pulp + lemon grass @2\%) & 56.18 & 57.19 & 58.24 & 59.55 & 60.82 & 62.35 & 63.17 \\
$\mathrm{~T}_{5}$ (Wood apple pulp + mango ginger @2\%) & 56.23 & 57.10 & 58.04 & 58.60 & 59.20 & 60.51 & 62.59 \\
$\mathrm{~T}_{6}$ (Control) & 56.24 & 57.24 & 58.48 & 61.00 & 63.89 & 65.22 & 67.45 \\
S.E. ( \pm ) & 0.13 & 0.05 & 0.10 & 0.14 & 0.10 & 0.11 & 0.18 \\
C.D. at 5\% & N/A & N/A & N/A & 0.42 & 0.31 & 0.34 & 0.53 \\
\hline
\end{tabular}

3.6 Change in reducing sugar content of jam during ambient storage

Table 6 depicts the effect of different medicinal herbs on reducing sugar (\%) of wood apple jam during 12 months of ambient storage. Just like the total sugar content, this parameter also showed an increase in value during period of ambient storage. An increasing trend was observed in reducing sugar content throughout the storage months. At 0 month of storage, no significant difference in reducing sugar was observed among the treatments. Highest reducing sugar content was observed in $\mathrm{T}_{6}$ followed by $\mathrm{T}_{4}, \mathrm{~T}_{2}, \mathrm{~T}_{3}, \mathrm{~T}_{1}$ and $\mathrm{T}_{5}$ which was $26.20 \%, 26.16 \%, 26.12 \%, 26.11 \%, 26.10 \%$ and $26.10 \%$, respectively. No significant difference among treatment was observed. At $2^{\text {nd }}$ month of storage, highest reducing sugar content was observed in $\mathrm{T}_{6}$ (Control) followed by $\mathrm{T}_{4}, \mathrm{~T}_{2}, \mathrm{~T}_{1}, \mathrm{~T}_{3}, \mathrm{~T}_{5}$ which was $26.98 \%, 26.93 \%, 26.91 \%, 26.90 \%, 26.89 \%$ and $26.74 \%$, respectively. No significant difference among treatment was observed even at $2^{\text {nd }}$ month. At $4^{\text {th }}$ month of storage, highest reducing sugar content was observed in $\mathrm{T}_{6}\left(\right.$ Control) followed by $\mathrm{T}_{3}, \mathrm{~T}_{4}, \mathrm{~T}_{5}$, $\mathrm{T}_{1}$ and $\mathrm{T}_{2}$ which was $28.94 \%, 27.80 \%, 27.80 \%, 28.12 \%, 27.12 \%$, and $27.26 \%$, respectively. At $6^{\text {th }}$ month of storage, highest reducing sugar content was observed in $\mathrm{T}_{6}$ followed by $\mathrm{T}_{4}, \mathrm{~T}_{2}, \mathrm{~T}_{1}, \mathrm{~T}_{3}$ and $\mathrm{T}_{5}$ 
which was $30.90 \%, 28.30 \%, 28.25 \%, 29.23 \%, 28.23 \%$ and $28.04 \%$, respectively. At $8^{\text {th }}$ month of storage, highest reducing sugar content was observed in $\mathrm{T}_{6}$ followed by $\mathrm{T}_{1}, \mathrm{~T}_{3}, \mathrm{~T}_{4}, \mathrm{~T}_{2}$ and $\mathrm{T}_{5}$ which was $31.60 \%, 30.89 \%, 30.47 \%, 29.80 \%, 29.16 \%$ and $28.97 \%$, respectively. At $10^{\text {th }}$ month of storage, highest reducing sugar content was observed in $\mathrm{T}_{6}$ followed by $\mathrm{T}_{1}, \mathrm{~T}_{3}, \mathrm{~T}_{2}, \mathrm{~T}_{4}$ and $\mathrm{T}_{5}$ which was $32.10 \%, 31.40 \%, 30.97 \%, 30.90 \%, 30.90 \%$ and $29.12 \%$, respectively. At $12^{\text {th }}$ month of storage, highest reducing sugar content was observed in $\mathrm{T}_{6}$ followed by $\mathrm{T}_{1}, \mathrm{~T}_{2}, \mathrm{~T}_{3}, \mathrm{~T}_{4}$ and $\mathrm{T}_{5}$ which was $33.90 \%, 32.10 \%, 31.15 \%, 31.12 \%, 31.10 \%$ and $30.89 \%$ respectively.

\subsection{Change in ascorbic acid content of jam during ambient storage}

Table 7 highlight the effect of natural herbs on ascorbic acid (mg/ $100 \mathrm{~g}$ ) content of wood apple jam during 12 months of ambient storage. A clear decline was observed in ascorbic acid content throughout the storage period. The treatments have a significant effect on the ascorbic acid content of wood apple jam in the $2^{\text {nd }}$ month, $4^{\text {th }}$ month, $6^{\text {th }}$ month, $8^{\text {th }}$ month, $10^{\text {th }}$ month and $12^{\text {th }}$ month of storage period. At 0 days of storage, the treatment exhibits no significant difference. At 0 days of storage, highest amount of ascorbic acid was observed in $\mathrm{T}_{6}$ (Control) followed by $\mathrm{T}_{1}, \mathrm{~T}_{3}, \mathrm{~T}_{4}$,
$\mathrm{T}_{5}$ and $\mathrm{T}_{2}$ which was $1.77 \mathrm{mg} / 100 \mathrm{~g}, 1.76 \mathrm{mg} / 100 \mathrm{~g}, 1.76 \mathrm{mg} / 100 \mathrm{~g}$, $1.75 \mathrm{mg} / 100 \mathrm{~g}, 1.75 \mathrm{mg} / 100 \mathrm{~g}$ and $1.74 \mathrm{mg} / 100 \mathrm{~g}$, respectively. At $2^{\text {nd }}$ day of storage, highest ascorbic acid content was observed in $\mathrm{T}_{5}, \mathrm{~T}_{1}, \mathrm{~T}_{2}, \mathrm{~T}_{4}, \mathrm{~T}_{6}$ and $\mathrm{T}_{3}$ which was $1.64 \mathrm{mg} / 100 \mathrm{~g}, 1.61 \mathrm{mg} / 100 \mathrm{~g}$, $1.59 \mathrm{mg} / 100 \mathrm{~g}, 1.56 \mathrm{mg} / 100 \mathrm{~g}, 1.51 \mathrm{mg} / 100 \mathrm{~g}$ and $1.49 \mathrm{mg} / 100 \mathrm{~g}$, respectively. At $4^{\text {th }}$ month of storage, highest amount of ascorbic acid was observed in $\mathrm{T}_{5}$ followed by $\mathrm{T}_{1}, \mathrm{~T}_{2}, \mathrm{~T}_{6}, \mathrm{~T}_{4}$ and $\mathrm{T}_{3}$ which was $1.53 \mathrm{mg} / 100 \mathrm{~g}, 1.49 \mathrm{mg} / 100 \mathrm{~g}, 1.48 \mathrm{mg} / 100 \mathrm{~g}, 1.4 \mathrm{mg} / 100 \mathrm{~g}$, $1.36 \mathrm{mg} / 100 \mathrm{~g}$ and $1.34 \mathrm{mg} / 100 \mathrm{~g}$, respectively. At $6^{\text {th }}$ month of storage, highest ascorbic acid was observed in $\mathrm{T}_{5}$ followed by $\mathrm{T}_{1}$, $\mathrm{T}_{4}, \mathrm{~T}_{2}, \mathrm{~T}_{3}$ and $\mathrm{T}_{6}$ which was $1.43 \mathrm{mg} / 100 \mathrm{~g}, 1.39 \mathrm{mg} / 100 \mathrm{~g}, 1.35 \mathrm{mg} /$ $100 \mathrm{~g}, 1.34 \mathrm{mg} / 100 \mathrm{~g}, 1.32 \mathrm{mg} / 100 \mathrm{~g}$ and $1.24 \mathrm{mg} / 100 \mathrm{~g}$, respectively. At $8^{\text {th }}$ month of storage, highest ascorbic acid content was observed in $\mathrm{T}_{5}$ followed by $\mathrm{T}_{1}, \mathrm{~T}_{4}, \mathrm{~T}_{2}, \mathrm{~T}_{3}$ and $\mathrm{T}_{6}$ which was $1.34 \mathrm{mg} / 100 \mathrm{~g}$, $1.26 \mathrm{mg} / 100 \mathrm{~g}, 1.21 \mathrm{mg} / 100 \mathrm{~g}, 1.19 \mathrm{mg} / 100 \mathrm{~g}, 1.16 \mathrm{mg} / 100 \mathrm{~g}$ and $1.03 \mathrm{mg} / 100 \mathrm{~g}$, respectively. At $10^{\text {th }}$ month of storage, highest ascorbic acid content was observed in $\mathrm{T}_{5}$ followed by $\mathrm{T}_{1}, \mathrm{~T}_{4}, \mathrm{~T}_{2}, \mathrm{~T}_{3}$ and $\mathrm{T}_{6}$ which was $1.28 \mathrm{mg} / 100 \mathrm{~g}, 1.20 \mathrm{mg} / 100 \mathrm{~g}, 1.16 \mathrm{mg} / 100 \mathrm{~g}$, $1.11 \mathrm{mg} / 100 \mathrm{~g}, 1.08 \mathrm{mg} / 100 \mathrm{~g}$ and $0.83 \mathrm{mg} / 100 \mathrm{~g}$, respectively. At $12^{\text {th }}$ month of storage, highest ascorbic acid content was observed in $\mathrm{T}_{5}$ followed by $\mathrm{T}_{4}, \mathrm{~T}_{1}, \mathrm{~T}_{2}, \mathrm{~T}_{3}$ and $\mathrm{T}_{6}$ which was $1.17 \mathrm{mg} / 100 \mathrm{~g}$, $1.11 \mathrm{mg} / 100 \mathrm{~g}, 1.08 \mathrm{mg} / 100 \mathrm{~g}, 1.03 \mathrm{mg} / 100 \mathrm{~g}, 0.96 \mathrm{mg} / 100 \mathrm{~g}$ and $0.51 \mathrm{mg} / 100 \mathrm{~g}$, respectively.

Table 6: Effect of natural herbs on reducing sugar (\%) of wood apple jam

\begin{tabular}{|c|c|c|c|c|c|c|c|}
\hline \multirow[t]{2}{*}{ Treatment details } & \multicolumn{7}{|c|}{ Months of storage } \\
\hline & $\mathbf{0}$ & 2 & 4 & 6 & 8 & 10 & 12 \\
\hline $\mathrm{T}_{1}($ Wood apple pulp + ashwagandha powder @ $2 \%)$ & 26.10 & 26.90 & 28.12 & 29.23 & 30.89 & 31.40 & 32.10 \\
\hline $\mathrm{T}_{2}($ Wood apple pulp + tulsi extract @ $2 \%)$ & 26.12 & 26.91 & 27.12 & 28.25 & 29.16 & 30.90 & 31.15 \\
\hline $\mathrm{T}_{3}($ Wood apple pulp + mint extract @2\%) & 26.11 & 26.89 & 27.80 & 28.23 & 30.47 & 30.97 & 31.12 \\
\hline $\mathrm{T}_{4}($ Wood apple pulp + lemon grass @2\%) & 26.16 & 26.93 & 27.80 & 28.30 & 29.80 & 30.90 & 31.10 \\
\hline $\mathrm{T}_{5}($ Wood apple pulp + mango ginger @2\%) & 26.10 & 26.74 & 27.26 & 28.04 & 28.97 & 29.12 & 30.89 \\
\hline $\mathrm{T}_{6}($ Control $)$ & 26.20 & 26.98 & 28.94 & 30.90 & 31.60 & 32.10 & 33.90 \\
\hline S.E. $( \pm)$ & 0.17 & 0.18 & 0.09 & 0.13 & 0.05 & 0.16 & 0.10 \\
\hline C.D. at $5 \%$ & N/A & N/A & 0.26 & 0.40 & 0.16 & 0.49 & 0.31 \\
\hline
\end{tabular}

Table 7: Effect of natural herbs on ascorbic acid $(\mathrm{mg} / 100 \mathrm{~g})$ of wood apple jam

\begin{tabular}{|c|c|c|c|c|c|c|c|}
\hline \multirow[t]{2}{*}{ Treatment details } & \multicolumn{7}{|c|}{ Months of storage } \\
\hline & $\mathbf{0}$ & 2 & 4 & 6 & 8 & 10 & 12 \\
\hline $\mathrm{T}_{1}$ (Wood apple pulp + ashwagandha powder @2\%) & 1.76 & 1.61 & 1.49 & 1.39 & 1.26 & 1.20 & 1.08 \\
\hline $\mathrm{T}_{2}($ Wood apple pulp + tulsi extract @2\%) & 1.74 & 1.59 & 1.48 & 1.34 & 1.19 & 1.11 & 1.03 \\
\hline $\mathrm{T}_{3}($ Wood apple pulp + mint extract @2\%) & 1.76 & 1.49 & 1.34 & 1.32 & 1.16 & 1.08 & 0.96 \\
\hline $\mathrm{T}_{4}($ Wood apple pulp + lemon grass @2\%) & 1.75 & 1.56 & 1.36 & 1.35 & 1.21 & 1.16 & 1.11 \\
\hline $\mathrm{T}_{5}($ Wood apple pulp + mango ginger @2\%) & 1.75 & 1.64 & 1.53 & 1.43 & 1.34 & 1.28 & 1.17 \\
\hline $\mathrm{T}_{6}$ (Control) & 1.77 & 1.51 & 1.4 & 1.24 & 1.03 & 0.83 & 0.51 \\
\hline S.E. $( \pm)$ & 0.01 & 0.02 & 0.02 & 0.01 & 0.02 & 0.02 & 0.02 \\
\hline C.D. at $5 \%$ & N/A & 0.05 & 0.07 & 0.04 & 0.06 & 0.05 & 0.07 \\
\hline
\end{tabular}

3.8 Change in total plate count $\left(10^{-5} \log\right.$ CFU $)$ of jam during ambient storage ( 1 to 9 hedonic scale)

Table 8 highlights the effect of natural herbs on total plate count $\left(10^{-5} \log \mathrm{CFU}\right)$ of wood apple jam during 12 months of ambient storage. However, wood apple itself is an acidic product with a low $\mathrm{pH}$ till then the bacterial population was found significantly growing in the control. At 0 days of storage, no significant differences among the treatments were observed. At 0 days of storage, the total plate count $\left(10^{-5} \log \mathrm{CFU}\right)$ of wood apple jam was $1.25,1.00,0.75,1.00$, 1.00 and 1.00 in $\mathrm{T}_{1}, \mathrm{~T}_{2}, \mathrm{~T}_{3}, \mathrm{~T}_{4}, \mathrm{~T}_{5}$ and $\mathrm{T}_{6}$, respectively. At $2^{\text {nd }}$ month of storage, no significant differences among the treatments were observed. Total colony count in $\mathrm{T}_{1}, \mathrm{~T}_{2}, \mathrm{~T}_{3}, \mathrm{~T}_{4}, \mathrm{~T}_{5}$ and $\mathrm{T}_{6}$ was 
$3.25,3.00,4.00,3.00,3.00$ and 3.75 , respectively. At $4^{\text {th }}$ month of storage, highest total bacteria colony count was observed in $\mathrm{T}_{6}$ followed by $\mathrm{T}_{3}, \mathrm{~T}_{4}, \mathrm{~T}_{2}, \mathrm{~T}_{1}$ and $\mathrm{T}_{5}$ which was $27.75,12.5,12.5$, $11.75,10.5$ and 7.5 , respectively. At $6^{\text {th }}$ month of storage, highest total bacteria colony count was observed in $\mathrm{T}_{6}$ followed by $\mathrm{T}_{2}, \mathrm{~T}_{4}$, $\mathrm{T}_{1}, \mathrm{~T}_{3}$ and $\mathrm{T}_{5}$ which was $51.25,24.25,23,21.75,21$ and 12.75 , respectively. At $8^{\text {th }}$ month of storage, highest total bacterial colony count was observed in $\mathrm{T}_{6}$ followed by $\mathrm{T}_{4}, \mathrm{~T}_{3}, \mathrm{~T}_{1}, \mathrm{~T}_{2}$ and $\mathrm{T}_{5}$ which was $65.50,36.75,33.25,31.00,30.00$ and 26.50, respectively. At $10^{\text {th }}$ month of storage, highest total bacterial colony count was observed in $\mathrm{T}_{6}$ followed by $\mathrm{T}_{3}, \mathrm{~T}_{4}, \mathrm{~T}_{1}, \mathrm{~T}_{2}$ and $\mathrm{T}_{5}$ which was 96.75 , $53.50,53.50,52.00,47.50$ and 42.25 , respectively. At $12^{\text {th }}$ month of storage, highest total bacterial colony count was observed in $\mathrm{T}_{6}$ followed by $\mathrm{T}_{3}, \mathrm{~T}_{4}, \mathrm{~T}_{2}, \mathrm{~T}_{1}$ and $\mathrm{T}_{5}$ which was $123.00,67.75,60.25$, $59.50,58.75$ and 49.00 , respectively.

3.9 Change in overall acceptability of jam during ambient storage

Overall response of any consumer towards its acceptability is most important factor towards determining success of any processed product. Table 9 highlights the effect of different natural herbs on overall acceptability of wood apple jam based on 9-point hedonic scale. At 0 days of storage, overall acceptability was highest in $\mathrm{T}_{5}$ followed by $\mathrm{T}_{6}, \mathrm{~T}_{3}, \mathrm{~T}_{4}, \mathrm{~T}_{1}$ and $\mathrm{T}_{2}$ which was $9.00,8.50,7.75,7.75$, 7.25 and 7.00 , respectively. At $2^{\text {nd }}$ month of storage, overall acceptability was highest in $\mathrm{T}_{5}$ followed by $\mathrm{T}_{6}, \mathrm{~T}_{3}, \mathrm{~T}_{4}, \mathrm{~T}_{1}$ and $\mathrm{T}_{2}$ which was $9.00,8.75,8.00,8.00,7.50$ and 7.25 , respectively. At $4^{\text {th }}$ month of storage, overall acceptability was highest in $\mathrm{T}_{5}$ followed by $\mathrm{T}_{6}, \mathrm{~T}_{3}, \mathrm{~T}_{4}, \mathrm{~T}_{1}$ and $\mathrm{T}_{2}$ which was $9.00,8.75,8.00,8.00,7.50$ and 7.25 , respectively. At $6^{\text {th }}$ month of storage, overall acceptability was highest in $\mathrm{T}_{5}$ followed by $\mathrm{T}_{6}, \mathrm{~T}_{3}, \mathrm{~T}_{4}, \mathrm{~T}_{1}$ and $\mathrm{T}_{2}$ which was 9.00 , $8.75,7.75,7.50,7.25$ and 7.00 , respectively. At $8^{\text {th }}$ month of storage, overall acceptability was highest in $\mathrm{T}_{5}$ followed by $\mathrm{T}_{6}, \mathrm{~T}_{4}, \mathrm{~T}_{3}, \mathrm{~T}_{1}$ and $\mathrm{T}_{2}$ which was $9.00,8.50,8.25,7.75,7.25$ and 7.00 , respectively. At $10^{\text {th }}$ month of storage, overall acceptability was highest in $\mathrm{T}_{5}$ followed by $\mathrm{T}_{6}, \mathrm{~T}_{4}, \mathrm{~T}_{3}, \mathrm{~T}_{1}$ and $\mathrm{T}_{2}$ which was $9.00,8.50,8.25,8.00$, 7.25 and 7.00, respectively. At $12^{\text {th }}$ month of storage, overall acceptability was highest in $\mathrm{T}_{5}$ followed by $\mathrm{T}_{4}, \mathrm{~T}_{6}, \mathrm{~T}_{3}, \mathrm{~T}_{1}$ and $\mathrm{T}_{2}$ which was $8.75,8.25,8.25,7.75,7.25$ and 7.00 , respectively.

Table 8: Effect of natural herbs on total plate count of wood apple jam $\left(10^{-5} \log \mathrm{CFU}\right)$

\begin{tabular}{|c|c|c|c|c|c|c|c|}
\hline \multirow[t]{2}{*}{ Treatment details } & \multicolumn{7}{|c|}{ Months of storage } \\
\hline & $\mathbf{0}$ & 2 & 4 & 6 & 8 & 10 & 12 \\
\hline $\mathrm{T}_{1}($ Wood apple pulp + ashwagandha powder @2\%) & 1.25 & 3.25 & 10.50 & 21.75 & 31.00 & 52.00 & 58.75 \\
\hline $\mathrm{T}_{2}($ Wood apple pulp + tulsi extract @2\%) & 1.00 & 3.00 & 11.75 & 24.25 & 30.00 & 47.50 & 59.50 \\
\hline $\mathrm{T}_{3}($ Wood apple pulp + mint extract @ $2 \%)$ & 0.75 & 4.00 & 12.50 & 21 & 33.25 & 53.50 & 67.75 \\
\hline $\mathrm{T}_{4}($ Wood apple pulp + lemon grass @2\%) & 1.00 & 3.00 & 12.50 & 23 & 36.75 & 53.50 & 60.25 \\
\hline $\mathrm{T}_{5}($ Wood apple pulp + mango ginger @2\%) & 1.00 & 3.00 & 7.50 & 12.75 & 26.50 & 42.25 & 49.00 \\
\hline $\mathrm{T}_{6}($ Control $)$ & 1.00 & 3.75 & 27.75 & 51.25 & 65.50 & 96.75 & 123.00 \\
\hline S.E. $( \pm)$ & 0.28 & 0.40 & 0.76 & 1.03 & 1.42 & 2.14 & 2.49 \\
\hline C.D. at $5 \%$ & N/A & N/A & 2.273 & 3.09 & 4.26 & 6.39 & 7.46 \\
\hline
\end{tabular}

Table 9: Effect of natural herbs on overall acceptability of wood apple jam (1 to 9 hedonic scale)

\begin{tabular}{|c|c|c|c|c|c|c|c|}
\hline \multirow[t]{2}{*}{ Treatment details } & \multicolumn{7}{|c|}{ Months of storage } \\
\hline & 0 & 2 & 4 & 6 & 8 & 10 & 12 \\
\hline $\mathrm{T}_{1}($ Wood apple pulp + ashwagandha powder @2\%) & 7.25 & 7.50 & 7.50 & 7.25 & 7.25 & 7.25 & 7.25 \\
\hline $\mathrm{T}_{2}($ Wood apple pulp + tulsi extract @2\%) & 7.00 & 7.25 & 7.00 & 7.00 & 7.00 & 7.00 & 7.00 \\
\hline $\mathrm{T}_{3}($ Wood apple pulp + mint extract @2\%) & 7.75 & 8.00 & 8.00 & 7.75 & 7.75 & 8.00 & 7.75 \\
\hline $\mathrm{T}_{4}($ Wood apple pulp + lemon grass @2\%) & 7.75 & 8.00 & 8.00 & 7.50 & 8.25 & 8.25 & 8.25 \\
\hline $\mathrm{T}_{5}($ Wood apple pulp + mango ginger @2\%) & 9.00 & 9.00 & 9.00 & 9.00 & 9.00 & 9.00 & 8.75 \\
\hline $\mathrm{T}_{6}($ Control $)$ & 8.50 & 8.75 & 8.50 & 8.75 & 8.50 & 8.50 & 8.25 \\
\hline S.Em. $( \pm)$ & 0.21 & 0.25 & 0.28 & 0.26 & 0.21 & 0.19 & 0.23 \\
\hline C.D. at $5 \%$ & 0.62 & 0.76 & 0.84 & 0.78 & 0.64 & 0.56 & 0.68 \\
\hline
\end{tabular}

\section{Discussion}

It is clearly visible that the wood apple jam which was subjected to ashwagandha, tulsi, mint, lemon, mango ginger exhibited a lower increased in TSS $\left({ }^{\circ} \mathrm{B}\right)$, total sugar $(\mathrm{mg} / 100 \mathrm{~g})$ and reducing sugar $(\mathrm{mg} / 100 \mathrm{~g})$. The higher increase of TSS value in case of control, indicates a higher rate of conversion of starch and other carbohydrate to simple sugar. In control clearly the increase in TSS is more. Significantly high total sugar content in $\mathrm{T}_{6}$ is due to the fact that rate of degradation of complex carbohydrate was more as compared to other treatment. Higher total sugar content in $\mathrm{T}_{6}$ is evident of the fact that the other treatments were able to somewhat retard the degradation process of the carbohydrate. The breakdown of more carbohydrate let to accumulation of more total sugar in wood apple jam prepared with no additives $\left(\mathrm{T}_{6}\right)$. This is because of the fact that in control treatment rate of degradation of complex carbohydrate to simple sugar was higher. The minimum rate of decline was observed in case of jam incorporated with mango ginger.

A higher decline in titratable acidity implies a higher rate of degradation of organic acid. Clearly, $\mathrm{T}_{6}$ with no herbal additives showed an enhanced rate of fall in titratable acidity. A faster increase 
in $\mathrm{pH}$ can be due to the reduction in titratable acidity of the jam. Vitamin $\mathrm{C}$ is important component of wood apple pulp. Retention of Vitamin C throughout the storage period is of utmost importance. Throughout the storage period, maximum loss in ascorbic acid was observed in jam prepared with no additives. Herbal additives ensured reduced loss of ascorbic acid in jam. Hence, the treatments with herbal additives exhibited minimum loss in ascorbic acid content as compared to that of the control where no additives were added $\left(\mathrm{T}_{6}\right)$. Shelf-life enhancement was possible only through addition of natural herbs. It was also evident that addition of ashwagandha, tulsi extract, mint extract, lemon grass and mango ginger resulted in lesser bacterial colony formation throughout the storage, Clearly effects of additives were very much prominent in reducing the total bacterial colony in jam. The jam with no additives $\left(\mathrm{T}_{6}\right)$ has significantly higher bacterial colony count at $10^{-5} \log$ CFU. The antibacterial property of the additives used can be a vital reason why the TPC was low in $\mathrm{T}_{1}, \mathrm{~T}_{2}, \mathrm{~T}_{3}, \mathrm{~T}_{4}$ and $\mathrm{T}_{5}$. Antibacterial property of ashwagandha was observed by Meher et al. (2016) and Mirjalili et al. (2009). Antibacterial property of tulsi extract was observed by Mishra and Mishra, (2011) and Singh et al. (2007). Antibacterial property of mint extract was also reported by Mickiene et al. (2011) and Biswas et al. (2014). Antibacterial property of lemon grass was reported by Naik et al. (2010).The main reason for poor acceptability of jam prepared with tulsi extract $\left(\mathrm{T}_{2}\right)$ is its poor texture and off flavour. Ashwagandha powder mixed jam $\left(\mathrm{T}_{1}\right)$ also renders the jam a slight bitter after taste and unpleasant aroma. Overall acceptability of $\mathrm{T}_{5}, \mathrm{~T}_{6}$ and $\mathrm{T}_{4}$ is consistently higher throughout the storage period. Throughout the storage period, the jam which was subjected to mango ginger treatment $2 \%$, exhibited a high acceptability in terms of hedonic score throughout the storage period. The mango ginger flavour along with the sour-sweet blend of the wood apple pulp was probably liked by the judges.

\section{Conclusion}

From the above study, it can be concluded that all the natural herbs have some desirable effect on improving the overall quality of wood apple jam. mango ginger can effectively be substituted in wood apple jam to ensure its consumable quality up to $12^{\text {th }}$ month of storage. It can be concluded that $\mathrm{T}_{5}(\mathrm{WAP}+$ Mango ginger @ 2\%) could be an ideal treatment to ensure quality wood apple jam which can not only enhance the product quality but also retain the quality up to $12^{\text {th }}$ month of ambient storage. The jam prepared with wood apple blended with mango ginger 2\% (Curcuma amada) can be commercially utilized.

\section{Acknowledgements}

This work has been conducted in Post Graduate Lab, Department of Post Harvest Technology, Faculty of Horticulture, BCKV, India

\section{Conflict of interest}

The authors declare that there are no conflicts of interest relevant to this article.

\section{References}

AOAC. (2012). Official methods of analysis of AOAC International, 19th edition, AOAC International, Gaithersburg, MD, USA.

Aapte, W. (2007). Sanskrit Hindi Shabdkosha, Anil Prakashan, Delhi, Caraka Samhita, 815(30):502-519.
Ahamed, S.M.; Swamy, S.K.; Jayaverra, K.N.; Rao, J.V. and Kumar, S. (2008). Anti-inflammatory, antipyretic and analgesic activity of methanolic extract of Feronia limonia. Pharmacology, 3(1):852-857.

Cohen, M.M. (2014). Tulsi - Ocimum sanctum: A herb for all reasons. Jour. of Ayurv. Integr. Med., 5(4):251-259.

Danlami, U.; Rebecca, A.; Machan, D.B. and Asuquo, T.S. (2011). Comparative study on the antimicrobial activities of the ethanolic extracts of Lemon grass and Polyalthia longifolia. J. of App. Pharma. Sci., 1(9): 174-176.

Dosoky, N.S. and Setzer, W.N. (2018). Chemical composition and biological activities of essential oils of curcuma species. Nutrients. 10:11961204. DOI: $10.3390 /$ nu 10091196

Gangrade, S.K.; Mishra, P.K.; and Sharma, R.K. (2000). Variability in essential oil constituents of Ocimum sp., J. of Med. Arom. Plant Sci., 22(1): 13-16.

Jana, S.N. and Charan, S.M. (2018). Health benefits and medicinal potency of Withania somnifera: A review. Int. J. Pharm. Sci. Rev. Res., 48(1):22-29.

Luthra, D. (2010). Ocimum Sanctum (Tulsi): A potent medicinal herb. webmed Central Pharmac., 1(11):WMC001210.

Majewska, E.;Kozlowska, M.; Gruczyńska-Sękowska, E.;Kowalska, D. and Tarnowska, K. (2019). Lemongrass (Cymbopogon citratus) essential oil: Extraction, composition, bioactivity and uses for food preservation: A review. Polish J. Food and Nutri. Sci., 69(4):327341. DOI: https://doi.org/10.31883/pjfns/113152.

Malek, S.N.; Lee, G.S.; Hong, S.L.; Yaacob, H.; Wahab, N.A.; Faizal, W.J.F. and Shah, S.A. (2011). "Phytochemical and cytotoxic investigations of Curcuma mangga rhizomes." Molecules, 16(6):4539-4548.

Mani, A. and Mitra, S. (2020). Nutritional and medicinal properties of wood apple. Agric.and Food: e-Newsletter, 2(5):71-72. DOI: 10.13140/ RG.2.2.19855.74403.

Nithya, N. and Saraswathi, U. (2010). In vitro antioxidant and antibacterial efficacy of Feronia elephantum. Correa aspects and reported medicinal plants having ant diabetic activity. Asian Pac. J. Trop. Biomed., 2(5):411-420.

Olorunnisola, S.K.; Asiyanbi, H.T.; Hammed, A.M. and Simsek, S. (2014). Biological properties of lemongrass: An overview. Int. Food Res. J., 21(2):455-462.

Patel, D.K.; Kumar, R.; Laloo D. and Hemalatha, S. (2012). Diabetes mellitus: An overview on its pharmacological. Phytochem., 59(1):73-77.

Peryam, D.R. and Pilgrim, F.J. (1957). Hedonic scale method of measuring food preferences. J. of Food Tech.,14:9-14.

Policegoudra, R.S.; Aradhya, S.M. and Singh, L. (2011). Mango ginger (Curcuma amadaRoxb.) - A promising spice for phytochemicals and biological activities. J. Biosci., 36:739-748. DOI 10.1007/ s12038-011-9106-1

Rahman, M.M. and Gray, A.I. (2002). Antimicrobial constituents from the stem bark of Feronia limonia fruit. Ind. J. of Natural Prod. and Res., 1(3):301-305.

Ranganna, S. (2010). Handbook of analysis and quality control for fruit and vegetable products, (Tata McGraw-Hill Education Private Ltd), New Delhi.

Rao, A.S., Rajanikanth, B. and Seshadri, R. (1989). "Volatile aroma components of Curcuma amada Roxb". J. Agric. Food Chem., 37(3):740-743. Doi:10.1021/jf00087a036 
Silva, C.B.; Guterres, S.S.; Weisheimer, V. and Schapoval, E.E. (2008). Antifungal activity of the lemongrass oil and citral against Candida spp. Braz. J. Infect. Dis., 12(1):63-66.

Sonawane, S. and Arya, S.S. (2013). Antioxidant activity of jambhul, wood apple, ambadi and ambat chukka: An indigenous lesser known fruits and vegetables of India. Adv. J. of Food Sci. and Tech., 5(3):270275 .

Tamta,A.; Prakash, O.;Punetha, H. and Pant, A.K. (2016). Chemical composition and in vitro antioxidant potential of essential oil and rhizome extracts of Curcuma amada Roxb. Cogent Chem., 2(1):1168067. http://dx.doi.org/10.1080/23312009.2016.1168067

Verma, S.K. and Kumar, A. (2011). Therapeutic uses of Withania somnifera (ashwagandha) with a note on withanolides and its pharmacological actions. Asian J. Pharma.and Clinical Res., 4(1):1-4.

Vidhya, R. and Narain V. (2011). Formulation and evaluation of preserved products utilizing under exploited fruit, wood apple (Limonia acidissima). American-Eurasian J. Agri. and Environ. Sci., 10(1):112-118 